\title{
Correction to: Prediction of autogenous shrinkage in concrete from material composition or strength calibrated by a large database, as update to model B4
}

\author{
Mohammad Rasoolinejad $\cdot$ Saeed Rahimi-Aghdam $\cdot$ Zdeněk P. Bažant
}

Published online: 24 June 2020

(C) The Author(s) 2020

\section{Correction to:}

Materials and Structures (2019) 52:33

https://doi.org/10.1617/s11527-019-1331-3

The article "Prediction of autogenous shrinkage in concrete from material composition or strength calibrated by a large database, as update to model B4", written by "Mohammad Rasoolinejad, Saeed RahimiAghdam, Zdeněk P. Bažant", was originally published electronically on the publisher's Internet portal (currently SpringerLink) on 11 March 2019 without open access.

The copyright of the article changed in May 2020 to The Author(s) 2020 and the article is forthwith distributed under the terms of the Creative Commons Attribution 4.0 International License (http:// creativecommons.org/licenses/by/4.0/), which permits use, duplication, adaptation, distribution and reproduction in any medium or format, as long as you give appropriate credit to the original author(s) and the source, provide a link to the Creative Commons license and indicate if changes were made.

Open Access This article is distributed under the terms of the Creative Commons Attribution 4.0 International License (http://creativecommons.org/ licenses/by/4.0/), which permits unrestricted use, distribution, and reproduction in any medium, provided you give appropriate credit to the original author(s) and the source, provide a link to the Creative Commons license, and indicate if changes were made.

Publisher's Note Springer Nature remains neutral with regard to jurisdictional claims in published maps and institutional affiliations.

The original article can be found online at https:// doi.org/10.1617/s11527-019-1331-3.

M. Rasoolinejad · S. Rahimi-Aghdam Graduate Research Assistant, Northwestern University, Evanston, IL, USA

Z. P. Bažant ( $\square)$

McCormick Institute Professor and W.P.

MurphyProfessor of Civil and Mechanical Engineering andMaterials Science, Northwestern University, 2145

Sheridan Road, CEE/A135, Evanston,

IL 60208, USA

e-mail: z-bazant@northwestern.edu 